\title{
Sustainable Development of Halal Tourism in Indonesia: Opportunities and Challenges
}

\author{
A Rasyid \\ Faculty of Humanities, Universitas Bina Nusantara, Jakarta, Indonesia \\ arasyid@binus.edu
}

\begin{abstract}
Halal tourism is growing rapidly in the last decades. The potential for the business of Halal tourism is very vast in line with the increasing economy of Muslim countries. Numerous countries, both Muslim and non-Muslim countries, are vying to become the centre of Halal tourism, including Indonesia. As a predominantly Muslim country and supported by magnificent natural resources, Indonesia can become the centre of world Halal tourism. But in fact, the Indonesian Halal Tourism is still lagging compared to other countries such as Malaysia, Thailand, and Singapore. This study provides a critical review of strategic and contemporary Halal Tourism development in Indonesia based on secondary data. In the end, this paper seeks to analyse the potential development of Halal tourism in Indonesia along with its opportunities and challenges that will be faced.
\end{abstract}

Keywords: Halal Tourism, Muslim Countries, Indonesia

\section{INTRODUCTION}

The rapid development of sharia banking and financial institutions in the world also affects the growth of other sharia business sector, one of which is halal tourism. Halal tourism business is a huge potential. Build on research reports by MasterCard \& Crescent Rating on the 'Global Muslim Travel Index (GMTI) 2015', by 2014 there are 108 million Muslims who have traveled at a cost of U \$ 145 billion. This figure represents about $10 \%$ of the total global tourism economy. By 2020, Muslim tourists are predicted to increase to 150 million at a cost of U\$ 200 billion [1].

Furthermore, the above research report stated that the Muslim population in the world will continue to grow. By 2030, the Muslim population is expected to represent $26.5 \%$ of the world's population. Majority of Muslim population comes from emerging economies countries, such as Indonesia, Turkey, and the Gulf States. Therefore, Muslims are important consumers in all business sectors including halal tourism business.

Based on the above data, halal tourism is a very potential business. The huge potential of this halal tourism business attracts the interest of various countries, both Muslim and nonMuslim countries, to develop it. For example, South Korea, Thailand, Singapore and Japan are ready to become halal tourism destinations by preparing numerous supporting facilities such as mosques, sharia hotels, and halal restaurants to attract Muslim tourists visiting the country.

In addition, Malaysia, Indonesia's neighbor, is also very serious in developing the halal tourism business. Currently, Malaysia is the most visited country by Muslims tourists [1]. Indonesia is currently also trying to develop halal tourism. As the largest Muslim country in 
the world and supported by magnificent natural resources, the potential of halal tourism in Indonesia is enormous. Numerous policies have been issued by the government to support the development of halal tourism. But the result is still not maximized. This paper aims to analyze the progress of halal tourism in Indonesia and the opportunities and challenges it faces.

\section{LITERATURE REVIEW}

There are several terms used in some countries related to the term halal tourism such as halal tourism, Islamic tourism, Islamic travel, halal travel, Muslim-friendly tourism, sharia tourism and halal transportation. Currently, many researchers, academics, businessman and practitioners use the terms "halal tourism" and "Islamic tourism". These terms are often used by them interchangeably as if the two concepts are alike. However, using 'halal tourism' and 'Islamic tourism at the same terms could be questionable [2]-[4].

It is important to emphasize that the terms 'halal' and 'Islamic', are different. Halal is defined as "that is permitted, which respect to which no restriction exists, and the doing of which the law-giver, Allah, is allowed. The halal term means 'permissible' according to Islamic teaching. Therefore, if the terms 'halal' is associated with tourism, it can be read as any practice or activity in tourism which is 'permissible' according to Islamic teaching. However, the term 'Islamic' is used specifically for the faith and its doctrines such as Islamic law/shariah, Islamic values, principles and beliefs and Islamic worship. Islam indicates that faith as an ideal based on the core Islamic sources which are the Quran and Sunnah. Furthermore, to ensure an activity is 'Islamic', the element of intention (niyyah) is required to be seen. An activity is accepted by God becomes Islamic when the intention of the person who performed it is to seek the pleasure of God [2]. Based on the above arguments, utilizing the term 'halal' as a brand name is better than the term 'Islamic' for any related product and service in the tourism industry.

Furthermore, accordingto a study commissioned by the COMCEC (2016), MuslimFriendly Tourism which was equated with halal tourism was defined as the activities of Muslim travelers who do not wish to compromise their faith-based needs while traveling for a purpose, which is permissible'[5]. Alhabse defines halal tourism as 'offering tour packages and destinations that are particularly designed to cater to Muslim considerations and address Muslim needs [6]. Battour\& Ismail defined it as 'any tourism object or action which is permissible according to Islamic teachings to utilize by Muslims in the tourism industry [3].' This definition implies that all products and services which are offered to customers who are mainly Muslims based on Islamic law (sharia) as the main sources. Those halal products and services such as halal hotels, halal restaurant, halal trips etc.

\subsection{Halal Tourism in Indonesia}

Currently, the tourism industry in Indonesia has always ranked 4th or 5th of the country's foreign exchange earners. Other sectors of business such as oil and gas, coal, rubber and textiles that occupies the first position in the fourth is inclined to decline in accordance with its character as 'non-renewable' products. These sectors are deemed to be surpassed by the tourism sector at the end of 2019, with a target of 20 million overseas tourists and 275 million domestic tourists. Therefore, the government sets tourism to be among the five leading sectors and provides a significant upward budget to achieve the main target of tourism development [7]. 
Indonesia is a predominantly Muslim country with the largest Muslim population in the world. Indonesia has magnificent natural resources. Therefore, the opportunity to become the main destination of halal tourism in the world is expected to be very considerable. To achieve this, in 2013, the Ministry of Tourism of the Republic of Indonesia in cooperation with the Indonesian Ulema Council (MUI) convened a Grand Launching of Sharia Tourism [8]. The purpose of this program is tantamount to attract tourists, both domestic and abroad, and to encourage the development of sharia business entities in the environment of halal tourism in Indonesia. The progress of halal tourism will be focused on four types of business, namely in the business of hotels, restaurants, bureaus or travel services, and spas. The Ministry of Tourism is further set three provinces as halal destinations. The three regions are Aceh, West Sumatra, and West Nusa Tenggara. Numerous products and facilities such as halal restaurants and accommodation have been developed to support these activities [8].

\subsection{Regulation of Halal Tourism}

Halal tourism in Indonesia has been operated based on Law No. 10 of 2009 on Tourism. Principally, this law generally regulates tourism in Indonesia. There is now no special regulation governing halal tourism in Indonesia. Activities of halal tourism are further regulated in the regulation issued by the Ministry of Tourism in the form of Ministerial Regulation. Although the word halal tourism is not mentioned explicitly in Law No. 10 of 2009 on Tourism, if we observe Article 1 (3) related to the definition of tourism, the phrase 'various tourism activities' in the definition of tourism indicates the permissibility of conducting tourism activities based on the principles of sharia. In principle, the business of halal tourism is a concept that integrates the values of sharia into tourism activities by providing facilities and services in accordance with the provisions of sharia. In addition, halal tourism business activities are feasible to run if supported by infrastructure facilities provided by the shareholders such as community, government, both central and local.

Out of four types of business of halal tourism, namely hotel, restaurant, bureau or travel services, and spa; only business of sharia hotel was issued its regulation by the Ministry of Tourism in 2014, i.e., the Regulation of the Minister of Tourism and Creative Economy of the Republic of Indonesia No. 2 of 2014 on Guidelines for the Implementation of Sharia Hotel Business. The issuance of this Regulation was based on the Memorandum of agreeing by the Ministry of Tourism and Creative Economy and the National Sharia Council - Indonesian Ulema Council (DSN-MUI) NK.11 / KS.001 / W.PEK / 2012 Number, B-459 / DSN-MUI / XII / 2012 on the Development and Socialization of Sharia Tourism. However, in 2016 this regulation was repealed by the Minister of Tourism of the Republic of Indonesia with Regulation No. 11 of 2016 on Revocation of Regulation of the Minister of Tourism and Creative Economy Number 2 of 2014 on the Guidelines for the Implementation of Sharia Hotel Business. The Minister of Tourism Regulation on Sharia Hotels was deleted because it was incompatible with the demands and developments of tourism today.

Furthermore, in 2016, the Minister of Tourism also issued Regulation No. 1 of 2016 on the Implementation of Tourism Business Certification. This regulation relates to the certification of business of halal tourism. According to Article 6 of this Regulation, the implementation of the certification of business of halal tourism shall be conducted by MUI. However, this Article was abolishedwith the issuance of Regulation of the Minister of Tourism of the Republic of Indonesia No. 12 of 2016 on Amendment of the Regulation of the Minister of Tourism No. 1 of 2016 on the Implementation of Tourism Business Certification. The revocation of this regulation may be related to the issuance of Law No. 33 of 2014 concerning Halal Product 
Guarantee, under which the Government should establish a Body of Product Halal Guarantee (BPJPH) to provide halal product guarantees. The role of MUl is only as the institution that issues the decision of halal product determination. Furthermore, in 2016, DSN-MUI) issued a fatwa No. 108/DSN-MUI on Guidance of Implementation of Tourism based on shariah. The halal tourism aspect which set out in the fatwa is related to hotels, spas, saunas, and massage, tourist attractions, and travel agencies.

\section{RESULT AND DISCUSSION}

Based on research conducted by MasterCard \&CrescentRating on 'Global Muslim Travel Index 2018', in 2018, the position of Indonesia is in the second position of the Organization of Islamic Conference Countries visited by many Muslim tourists in the world [9]. The first position is still positioned by Malaysia. The position of Indonesia in 2018 is better than the previous year, up one level wherein 2017 was in the third position. The rise in Indonesia's position in the second position based on the MasterCard \&CrescentRating research version above indicates that there has become a significant change in the management of halal tourism in Indonesia. Numerous policies have been taken by the Ministry of Tourism to attract Muslim tourists to Indonesia. The potential ten provinces namely, Aceh, West Sumatra, Riau \& Riau Islands, Jakarta, West Java, Central Java, D.I Yogyakarta, East Java, Lombok NTB and South Sulawesi are specially prepared as a worthy halal tourism place to visit.

Based on the above research, it can be understood that Indonesia has great potential to become a major player of halal tourism. Currently, Indonesia is one of the halal favorite tourism destinations among foreign Muslim tourists. This is because Indonesia has many beautiful places and has the largest Muslim population in the world. Furthermore, the culture of Indonesian society is also in line with the characteristics of halal tourism as well as the emergence of awareness of the stakeholders of the importance of halal tourism.

Although halal tourism in Indonesia has been developing significantly, according to Sofyan, the Chairman of the Halal Tourism Acceleration Team of the Ministry of Tourism, there are still some challenges faced in developing halal tourism in Indonesia. First, there is still an assumption that halal tourism is not a lucrative business market share so that efforts to improve halal tourism by the stakeholders are not maximal. Second, since it is halal tourism and majority of Indonesian people are Muslim, there is also an assumption by the community not to make the innovation to the existing facilities and infrastructures since there are already considered halal [10]. Some of the above assumptions can deliberately slow the development of halal tourism in Indonesia. However, in Malaysia, though majority of its population are Muslim, the efforts to improve halal tourism remain to be done by the government by providing a variety of convenient facilities and infrastructures to attract foreign Muslim tourists. Therefore, it cannot be denied that Malaysia become main tourist destination for Muslim tourists around the world.

In addition, besides some of the challenges mentioned above, in my opinion, there are some additional challenges that led to the slow progress of halal tourism in Indonesia. First, there is not any specific regulation that specifically regulates halal tourism in Indonesia. The legal basis for halal tourism activities based on Law No. 10 of 2009 on Tourism is not clearly regulated halal tourism. Previously, there was Regulation of the Minister of Tourism and Creative Economy No. 2 of 2014 on Guidelines for the Implementation of Sharia Hotel Business, but that Regulation was revoked by the Minister of Tourism Regulation No. 11 of 2016. Furthermore, in 2016, DSN-MUI issued Fatwa Number 108 / DSN-MUI / X / 2016 on Guidelines for the Implementation of Tourism based on Sharia. However, such fatwa cannot 
apply effectively if it is not applied in the form of tourism minister's regulation. Therefore, the government is supposed to immediately create regulatory standards related to hotels, spas, saunas and messages, tourist objects and travel agencies based on DSN-MUI fatwa above.

Second, Law No. 33 of 2014 on Halal Product Guarantee, as a legal umbrella of halal products in Indonesia, which is expected to increase and accelerate the growth of the halal industry has not felt its influence significantly on the growth and acceleration of the halal industry. The Body of Product Halal Guarantee (BPJPH), which was just established on October 17, 2017, has also not been running optimally. Until now, BPJPH is still not ready to accept the application of halal certification. Another obstacle is the lack of a Halal Inspection Agency (LPH) that is accredited by BPJPH and MUI. The requirements for the establishment of LPH must first have a halal auditor certified by the MUI, in accordance with the provisions of Article 14 paragraph (2) letter $\mathrm{f}$ of the Halal Product Guarantee Act. The standard of halal auditor certification and LP accreditation has not been formulated by BPJPH and MUI.

Third, the lack of good infrastructure in halal tourism in Indonesia. For example, currently, not many hotels operate based on sharia principles and halal certified restaurants. Unlike the case, when we compare with Malaysia and Singapore which has shariah hotels and halal certified restaurants which are quite a lot from Indonesia. The lack of both facilities is a challenge for the development of halal tourism in Indonesia. Therefore, both central and local government must be synergized together in providing excellent facilities and infrastructure in accordance with sharia so that the interest of foreign Muslim tourists to come to Indonesia is greater.

\section{CONCLUSION}

By virtue of the above discussion, it can be understood that halal tourism in Indonesia has great potential to grow rapidly. This is because Indonesia is supported by many beautiful sites and most of the population are Muslim. However, it is important to note that such potential will not be able to develop maximally if not be managed properly. Therefore, in order to sustain development of halal tourism in Indonesia, full support from the government is obviously required. Furthermore, the numerous challenges as discussed above must be solved immediately so that halal tourism in Indonesia can improve significantly and compete with other countries.

\section{REFERENCES}

[1] MasterCard \& Crescent Rating, “Global Muslim Travel Index (GMTI)," 2015.

[2] H. El-Gohary, "Halal tourism, is it really Halal?," Tour. Manag. Perspect., vol. 19, pp. 124-130, Jul. 2016.

[3] M. Battour and M. N. Ismail, "Halal tourism: Concepts, practises, challenges and future," Tour. Manag. Perspect., vol. 19, pp. 150-154, Jul. 2016.

[4] A. Mohsin, N. Ramli, and B. A. Alkhulayfi, "Halal tourism: Emerging opportunities," Tour. Manag. Perspect., vol. 19, pp. 137-143, Jul. 2016.

[5] COMCEC, "Muslim Friendly Tourism: Understanding the Demand and Supply Sides in the OIC Member Countries," Ankara, 2016.

[6] E. D. Satriana and H. D. Faridah, "Halal Tourism: Development, Chance and Challenge," J. Halal Prod. Res., vol. 1, no. 2, pp. 32-43, 2018.

[7] Minister of Tourism Republic of Indonesia, "World Tourism Day Commemoration and National Tourism Day 2015," Kementerian Pariwisata Republik Indonesia, 2015. 
[Online]. Available: http://www.kemenpar.go.id/asp/detil.asp?c=125\&id=2975.

[8] Pariwisata Syariah, "Grand Launcing Pariwisata Syariah Indonesia," Pariwisata Syariah, 2013. [Online]. Available: https://pariwisatasyariah.wordpress.com/2013/11/20/grand-launching-pariwisatasyariah-indonesia/.

[9] Mastercard-Crescentrating, "Global Muslim Travel Index 2018," 2018.

[10] A. Rasyid, "Peluang dan Tantangan Wisata Halal di Indonesia," Binus University Faculty of Humanities, 2017. [Online]. Available: http://businesslaw.binus.ac.id/2017/11/18/peluang-dan-tantangan-wisata-halal-di-indonesia/. 